Original Article

Artigo Original

Vanessa Barcelos de Farias

Pricila Sleifer ${ }^{1}$

Luciane Ferreira Pauletti

Cristiane Fernandes Diehl Krimberg ${ }^{2}$

Keywords

Electrophysiology

Auditory-evoked potentials

Hearing loss

Infant

Audiometry

Auditory perception

Descritores

Eletrofisiologia

Potenciais evocados auditivos

Perda auditiva

Lactente

Audiometria

Percepção auditiva

Correspondence address:

Pricila Sleifer

Departamento de Saúde e Comunicação Humana, Instituto de Psicologia, Universidade Federal do Rio Grande do Sul, Rua Ramiro Barcelos, 2.600, Porto Alegre (RS), Brasil, CEP: 90035-003.

E-mail: pricilasleifer@uol.com.br

\section{Correlation of the findings of auditory steady-state evoked potential and of behavioral hearing assessment in infants with sensorineural hearing loss}

\author{
Correlação dos achados do potencial evocado auditivo \\ de estado estável e da avaliação auditiva comportamental \\ em lactentes com perda auditiva sensorioneural
}

\begin{abstract}
Purpose: To correlate the findings of an open-field audiometry with the thresholds of steady-state auditoryevoked potentials (SSAEPs) found in infants of up to 6 months of age with sensorineural hearing loss. Methods: This study included 19 infants with sensorineural hearing loss (8 males and 11 females), with minimum age of 2 months and maximum age of 6 months. The SSAEPs were assessed at 500 and $2000 \mathrm{~Hz}$, and the audiometry was performed in open field through observation of behavioral responses to sound stimuli, at the same frequencies. Results: We observed a significant correlation between the findings of both tests conducted at 500 and $2000 \mathrm{~Hz}$, with p-values of 0.002 and 0.013 , respectively. There was no statistical difference between ears $(\mathrm{p}=0.532)$ and genders $(\mathrm{p}=0.615)$. Conclusion: We conclude that there was a significant correlation between the SSAEP thresholds and the findings of the open-field audiometry. Therefore, we can affirm that the SSAEPs are a viable examination, able to predict the degree and configuration of hearing loss in infants of up to 6 months of age, and that they can be included in the clinical routine of hearing assessments conducted in children.
\end{abstract}

\section{RESUMO}

Objetivo: Correlacionar os achados da audiometria infantil em campo livre com os limiares do Potencial Evocado Auditivo de Estado Estável (PEAEE) encontrados em lactentes de até 6 meses de idade com perda auditiva sensorioneural. Métodos: Foram incluídos no estudo 19 lactentes, oito do gênero masculino e 11 do feminino, com idade mínima de 2 e máxima de 6 meses, que apresentaram perda auditiva sensorioneural. Foi realizada a pesquisa do PEAEE nas frequências de 500 e $2.000 \mathrm{~Hz}$ e realizada a audiometria em campo livre por meio da observação das respostas comportamentais frente a estímulos sonoros, nas mesmas frequências. Resultados: Observamos correlação significativa entre os achados das duas testagens nas frequências de 500 e $2.000 \mathrm{~Hz}$, sendo os valores de $\mathrm{p}=0,002$ e p=0,013, respectivamente. Não houve diferença estatística entre orelhas $(p=0,532)$ e gêneros $(p=0,615)$. Conclusão: Concluímos que há correlação significativa entre os limiares do PEAEE e os achados obtidos na audiometria infantil em campo livre. Sendo assim, podemos afirmar que o PEAEE é um exame viável, capaz de predizer o grau e a configuração da perda auditiva em lactentes menores de 6 meses, podendo ser incluído na rotina clínica da avaliação audiológica infantil.

Study carried out at the Department of Health and Human Communication, Universidade Federal do Rio Grande do Sul - UFRGS - and at Hospital Nossa Senhora da Conceição - HNSC - Porto Alegre (RS), Brazil. (1) Department of Health and Human Communication, Speech-Language Pathology and Audiology Program, Universidade Federal do Rio Grande do Sul - UFRGS - Porto Alegre (RS), Brazil.

(2) Hospital Nossa Senhora da Conceição - HNSC - Porto Alegre (RS), Brazil.

Source of funding: Institutional Program of Scientific Initiation Scholarships (PIBIC) and National Council for Scientific and Technological Development (CNPq).

Conflict of interests: nothing to declare. 


\section{INTRODUCTION}

Hearing is a prerequisite for the spontaneous acquisition and development of oral language, as well as for receiving and imparting knowledge ${ }^{(1-3)}$. Moreover, congenital hearing loss is the most prevalent human communication disorder worldwide $^{(4,5)}$. Therefore, it is important to identify hearing losses still in early childhood through the universal neonatal hearing screening (UNHS) to provide infants with early interventions and shorten the time lived with hearing $\operatorname{loss}^{(5,6)}$.

Because hearing assessments conducted through observing behavioral responses to sound stimuli are a frequently unreliable method to determine auditory thresholds in infants younger than 6 months of age ${ }^{(7,8)}$, researchers have increasingly attempted to describe this population's electrophysiological responses to obtain more consistent and objective responses that are conducive to hearing estimates and confirmation of early diagnoses of hearing $\operatorname{loss}^{(6,8-18)}$.

Currently, steady-state auditory-evoked potentials (SSAEPs) have been investigated. Among their great advantages, the SSAEPs stimulate various frequencies in both ears simultaneously, which positively influences the duration of this assessment. Moreover, it is possible to measure residual hearing, as the stimuli can reach levels close to $125 \mathrm{dBNH}$, thus allowing for assessments of a broader frequency range than through brainstem auditory-evoked potentials (BAEPs), from 250 to $8000 \mathrm{~Hz}$, and responses are present even when BAEPs are absent ${ }^{(6,10,16,19-23)}$.

The SSAEPs are repetitive electrophysiological responses to tones presented continuously, modulated in amplitude and frequency. They are obtained through a fast presentation of stimuli, which does not allow the nervous system to return to its initial condition. Thus, a specific stimulus evokes a cycle of responses that superimpose themselves to the response caused by the subsequent stimulus, and the nervous system keeps on responding. This continuous neural response is called steady state $^{(6,8,19-21)}$.

Some authors have shown the applicability of the SSAEPs and a significant correlation between minimum response levels (MRLs), BAEP electrophysiological thresholds, and results of behavioral hearing assessments in infants and children with normal hearing ${ }^{(9,10,12,15-17,22,24)}$, but only a few studies have been carried out describing the use of the SSAEPs in infants with hearing loss and small children who are difficult to be evaluated solely through behavioral assessments $^{(9-11,18-20,25)}$.

In light of this, and to contribute towards the advancement of research in this area, in this study our purpose was to correlate the findings obtained from behavioral hearing assessments to the MRLs of the SSAEPs in infants of up to 6 months of age with sensorineural hearing loss.

\section{METHODS}

This study was conducted at the Hearing Health Ambulatory of Hospital Nossa Senhora da Conceição (HNSC), in partnership with the Speech-Language Pathology and Audiology program of Universidade Federal do Rio Grande do Sul (UFRGS). It was approved by the ethics committees of the HNSC (protocol no. 11.137) and of the UFRGS Psychology Institute (protocol no. 2011.039).

The parents or legal guardians of the infants were duly informed about the purposes of this study, and they agreed to participate by signing the informed consent form. We pledged to use the information collected only for scientific purposes, and kept the patients' data confidential.

We included 19 infants in the study (8 males and $11 \mathrm{fe}-$ males), for a total of 38 ears tested. The individuals had either failed the UNHS conducted by the HNSC or been referred by the hearing health network of the State of Rio Grande do Sul because they did not pass the UNHS in their original location, from March 2011 to March 2012. Their minimum age was 2 months, the maximum age was 6 months, and the average was 4 months. To be included in this study, the participants had to meet the following criteria: having undergone an otorhinolaryngological assessment; presenting no complaints about alterations in the external and/or middle ear; presenting no impediments that could interfere with the examinations, such as, secretions, earwax, or foreign body in the external ear; having previously undergone transient-evoked otoacoustic emissions (TEOAEs), BAEPs, and frequency-specific BAEPs (FS-BAEPs); having air and bone pathways with altered responses; and presenting tympanometry with a type-A curve, according to Jerger ${ }^{(26)}$.

The TEOAEs were conducted with a Biologic device (model Scout) and were considered altered when the signalto-noise ratio was lower than $6 \mathrm{~dB}$ in three consecutive frequencies, with a reproducibility of $75 \%$ in each frequency and overall reproducibility higher than or equal to $70 \%(4,5,7)$.

The BAEPs were obtained with a Smart EP device manufactured by Intelligent Hearing Systems (IHS) and in-ear ER$3 \mathrm{~A}$ earphones. A stimulus of $80 \mathrm{dBHL}$ was used to assess the integrity of the auditory pathway. Using the same device, we investigated the FS-BAEPs at 500 and $2000 \mathrm{~Hz}$, with normality criteria of 35 and $30 \mathrm{dBHL}$, respectively ${ }^{(13,14)}$.

We investigated the measurements of acoustic immittance with a $1000-\mathrm{Hz}$ catheter and an Interacoustics device (model AT235H). They were considered altered in the presence of a maximum peak of complacency or when the latter was duplicated, decreased, or pointed to negative pressure. These are the standards suggested by the American SpeechLanguage-Hearing Association (ASHA) ${ }^{(4)}$ and by Alvarenga ${ }^{(7)}$. The clinical evaluations of the condition of the external and middle ears were carried out by an otorhinolaryngologist through otoscopy.

To investigate the SSAEPs, we also used an IHS Smart EP device and in-ear ER-3A earphones. The MRLs were detected through stimulation by a complex acoustic signal formed by carrier frequencies of 500 and $2000 \mathrm{~Hz}$, bilaterally, modulated with amplitudes of 77 and $93 \mathrm{~Hz}$ in the left ear, and of 79 and $95 \mathrm{~Hz}$ in the right ear. The reference electrodes were placed on the right (A2) and left (A1) mastoid, and the active $(\mathrm{Fz})$ and earth $(\mathrm{Fpz})$ electrodes were placed on the forehead. 
Before placing the electrodes, the necessary body part was cleaned with an abrasive paste (Nuprep $\left.{ }^{\circledR}\right)$. The impedance was maintained at or below $5 \mathrm{k} \Omega$. The thresholds were determined by descending the $\mathrm{dB} 20$ by 20 and increasing them 10 by 10 ; once close to the minimum threshold, the $\mathrm{dB}$ varied 5 by 5 . The initial intensity was around $70 \mathrm{dBHL}$, and the minimum intensity was $0 \mathrm{dBHL}^{(21)}$. All children needed to undergo the investigation of their auditory-evoked potentials in more than one session.

We highlight that, during the process of testing the SSAEPs, the MRLs were obtained in dBSPL, and the results were then converted to dBHL, according to the conversion table of the equipment use, that is, subtracting $26 \mathrm{~dB}$ at a $500-\mathrm{Hz}$ frequency and $13 \mathrm{~dB}$ at a $2000-\mathrm{Hz}$ frequency.

The open-field audiometry conducted through observing behavioral responses to sound stimuli was carried out with an Interacoustics audiometer (model AC30), with visual reinforcement in an acoustic booth. The infant was positioned on his/her mother's or legal guardian's lap or on a specific chair at a distance of $70 \mathrm{~cm}$ from the speakers, $0^{\circ}$ azimuth, in medial position to the sound boxes and the visual stimuli. The observation of behavioral responses with visual reinforcement followed an application protocol based on international $^{(27)}$ and national ${ }^{(7,28,29)}$ studies. We highlight that the open-field audiometry was conducted simultaneously by two speech-language audiologists who had no access to the SSAEP results obtained by other speech-language audiologists. Moreover, the SSAEP results were analyzed by two speech-language audiologists. All the data were analyzed by three different evaluators, two speech-language audiologists and one speech-language pathology and audiology student, on different occasions.

We researched the frequencies of 500 and $2000 \mathrm{~Hz}$, with the stimulus initially presented at an intensity of $80 \mathrm{dHL}$ or higher, descending 10 by 10 and ascending 5 by $5^{(7)}$. We considered the following responses as behavioral responses to sound stimuli: cochleopalpebral reflex, lateralocular movement, lateral sound localization, increased or decreased pacifier suction, smiling, crying, attention, startling, frowning, and general body movements, among others, as described in the literature consulted $^{(7,27-29)}$.

A databank based on the protocols used was assembled with Microsoft Excel. We used Wilcoxon's test to compare the findings of both evaluations. McNemar's test was used to analyze the correlation coefficients between the SSAEP thresholds, the open-field audiometry thresholds, and the degrees of hearing loss.

The analyses were performed with the program Statistical Package for the Social Sciences (SPSS), version 17.0, and the level of significance adopted was $5 \%(\mathrm{p} \leq 0.05)$. The categorical data were presented in relative frequency, and the quantitative data were yielded through averages.

\section{RESULTS}

During the conduction of this study, we assessed 19 infants who met the inclusion criteria and totalized 38 ears analyzed.
The sample's characteristics are displayed in Table 1. All infants had bilateral sensorineural hearing loss.

There was significant correlation between the SSAEP results and the findings of the open-field audiometry, as shown in Table 2.

We did not observe any significant correlation between the genders $(\mathrm{p}=0.615)$ or the ears $(\mathrm{p}=0.532)$.

The analysis of the correlation coefficients found between the SSAEP thresholds and the open-field audiometry thresholds is presented in Table 3. We observed a more marked correlation between severe and profound degrees of hearing loss.

The findings of the open-field audiometry by observing behavioral responses to sound stimuli were correlated with the SSAEP results of the better ear.

According to our initial proposal, we would research the frequencies of 500,1000, 2000, and $4000 \mathrm{~Hz}$ in both testing sessions, but some infants did not conclude their SSAEP assessments within the period of collection. Therefore, we considered the responses obtained at 500 and $2000 \mathrm{~Hz}$, as these were tested in all infants.

Table 1. Characteristics of the sample

\begin{tabular}{lc}
\hline Characteristics & $\mathrm{n}=19$ \\
\hline Age (months) & \\
Average (min-max) & $4(2-6)$ \\
Gender - $\mathrm{n}(\%)$ & \\
Male & $8(42)$ \\
Female & $11(58)$ \\
\hline
\end{tabular}

Caption: $\min =$ minimum $; \max =$ maximum

Table 2. Comparison of the thresholds obtained through the SSAEPs and the open-field behavioral audiometry at the frequencies of 500 and $2000 \mathrm{~Hz}$

\begin{tabular}{cccc}
\hline $\begin{array}{c}\text { Frequency } \\
\text { tested }(\mathrm{Hz})\end{array}$ & $\begin{array}{c}\text { SSAEP } \\
\text { Mn (min-max) }\end{array}$ & $\begin{array}{c}\text { Behavioral } \\
\text { audiometry } \\
\text { Mn (min-max) }\end{array}$ & p-value* \\
\hline 500 & $70(35-110)$ & $70(40-\downarrow)$ & 0.002 \\
2.000 & $80(50-\downarrow)$ & $85(50-\downarrow)$ & 0.013 \\
\hline
\end{tabular}

*Wilcoxon's test

Caption: $\mathrm{Mn}=$ mean; $\min =$ minimum value $; \max =$ maximum value $; \downarrow=$ absence of response at the equipment's maximum intensity

Table 3. Correlation coefficients between the thresholds of the steadystate auditory-evoked potentials, open-field audiometry thresholds, and the degrees of hearing loss

\begin{tabular}{lc}
\hline Intensity $(\mathrm{dB})$ & Coefficient $^{*}$ \\
\hline $35-40$ & 0.52 \\
$41-55$ & 0.58 \\
$56-70$ & 0.72 \\
$71-90$ & 0.83 \\
Higher than 90 & 0.95 \\
\hline
\end{tabular}

*McNemar's test 


\section{DISCUSSION}

The use of increasingly more objective tools to evaluate infants younger than 6 months of age and very small children is essential to detect hearing loss early, thus reducing the time lived with hearing loss and avoiding possible developmental deficits.

Among the procedures used in hearing assessments of children, the SSAEPs have stood out and studies have been increasingly carried out due to the great advantages, among which we cite the objectivity of the answers yielded, providing an electrophysiological threshold ${ }^{(6,7,19-21)}$.

The results presented in this study point to a strong correlation between the SSAEP results and the thresholds obtained in the open-field audiometry with observation of behavioral responses in the population studied. These results corroborate the findings described in similar studies found in the literature published over the past years ${ }^{(6,11,12,15,18,22,25)}$.

We verified that the value of $\mathrm{p}$ at $500 \mathrm{~Hz}$ indicated a stronger correlation than the one obtained at $2000 \mathrm{~Hz}$, a fact also presented by other authors ${ }^{(6,20)}$. However, this fact is contrary to some studies in which the authors report more marked correlations at high frequencies, because cochlear tonotopy and a higher energy concentration of the stimuli are found in this range $e^{(8,9,11)}$.

Upon analyzing the correlation coefficients found between the SSAEP thresholds, the open-field audiometry thresholds, and the degrees of hearing loss, we verified significant correlations in all degrees. We observed a stronger correlation between the severe and profound degrees, a fact that is in agreement with findings described in the literature, stronger even than those found in individuals with normal hearing, probably due, according to the authors, to the presence of recruitment ${ }^{(6,10,15,18,20,25,30)}$, which facilitates the identification of a stimulus.

Upon comparing the SSAEP responses between the ears separately and between the sexes, we did not detect any significant correlations, and this finding corroborates those described by other authors ${ }^{(19,30)}$.

We noticed that the difference between the thresholds of both evaluations was, on average, $10 \mathrm{~dB}$ at $500 \mathrm{~Hz}$ and $15 \mathrm{~dB}$ at $2000 \mathrm{~Hz}$. Similar differences were found in other studies $^{(6,8,9,12,15,18,19,25,30)}$. Some authors have reported that these differences tend to decrease as age progresses, as the degree of hearing loss becomes more severe, and also according to the frequency tested, and that they are less noticeable in high frequencies ${ }^{(11,12,15,17,20,22)}$. We can suppose that, most probably, such remarkable differences between the results of the evaluations conducted are due to the sample's age, which did not surpass 6 months. Moreover, the fact that the greatest difference was found at $2000 \mathrm{~Hz}$ does not corroborate other studies in which the authors report greater differences at $500 \mathrm{~Hz}^{(8,11)}$; nevertheless, our findings are similar to those of other studies that indicate greater differences in higher frequencies ${ }^{(22,30)}$. This difference can be attributed to the methodology used, as there are other equipment, protocols, and software programs for data analysis, as well as other types of stimuli used in research. It can also be attributed to the characteristics of the hearing losses of the infants assessed, and to the age differences within the group analyzed. Furthermore, we believe that the number of participants may have been a limiting factor in this study.

Despite this difference, the behavioral responses observed were consistent, and the significant correlation between the two tests indicates that the SSAEPs, when conducted in infants younger than 6 months of age, can objectively provide important data that ensure early and better interventions in each case. Furthermore, due to the great advantages of this procedure in comparison to other hearing examinations carried out with small children, it provides an important support for the selection and fitting of hearing devices, as well as referrals for cochlear implants. However, the results must not be used in isolation and must not exclude hearing assessments with observation of behavioral responses to sound stimuli.

\section{CONCLUSION}

At the end of this study, we verified that there was a significant correlation between the SSAEP thresholds and the findings of the open-field audiometry performed in infants with sensorineural hearing loss. We also observed a significant correlation between the thresholds and the degrees of hearing loss, more markedly in relation to the severe and profound degrees. There was no significant correlation among the SSAEP values regarding the variables ear and gender.

Therefore, we can affirm that the SSAEPs are a viable examination able to predict the degree and configuration of hearing loss in infants of up to 6 months of age, and they can be included in the clinical routine of hearing assessments conducted in children, considering the importance of more objective methods that aim at detecting hearing loss in its early stages and ensuring the most adequate conduct for each case. Nevertheless, we understand that more studies must be conducted on this topic, with a larger number of participants and the purpose of standardizing and characterizing this procedure.

\section{ACKNOWLEDGMENTS}

We acknowledge the financial support provided by CNPq (National Council for Scientific and Technological Development), especially PIBIC (Institutional Program of Scientific Initiation Scholarships), for this research through the scientific initiation scholarship granted to one of the researchers.

*CFDK collaborated with data collection and tabulation; LFP collaborated with data collection and tabulation; PS was responsible for the study outline, supervised data collection and collaborated with data tabulation and analysis, as well as manuscript elaboration; VBF was responsible for the study outline, supervised data collection and collaborated with data tabulation and analysis, as well as manuscript elaboration. 


\section{REFERENCES}

1. Hilú MRPB, Zeigelboim BS. O conhecimento, a valorização da triagem auditiva neonatal e a intervenção precoce da perda auditiva. Rev CEFAC 2007;9(4):563-70.

2. Gatto CI, Tochetto TM. Deficiência auditiva infantil: implicações e soluções. Rev CEFAC. 2007;9(1):110-15.

3. Costa SS. Audição, comunicação e linguagem. In: Costa SS, Cruz OLM, Oliveira JAA. Otorrinolaringologia: princípios e práticas. 2a ed. Porto Alegre: Artmed; 2006. p. 342-55.

4. American Speech-Language-Hearing Association (ASHA) (1997) [Internet]. Guidelines for Audiologic Screening [Guidelines]. [cited 2012 Aug 8] Available from: http://www.asha.org/policy/GL199700199.htm

5. Grupo de Apoio à Triagem Auditiva Neonatal Universal (GATANU) (2007) [Internet]. [cited 2012 Mar 19]. Available from: http://www. gatanu.org

6. Rodrigues GRI, Lewis DR. Potenciais evocados auditivos de estado estável em crianças com perdas auditivas cocleares. Pró-Fono R Atual Cient. 2010;22(1):37-42.

7. Alvarenga KF. Avaliação audiológica em bebês: 0 a 1 ano de idade. In: Bevilaqua MC, Martinez MAN, Balen SA, Pupo AC, Reis ACMB, Frota S. Tratado de Audiologia. São Paulo: Santos; 2011. p. 517-32.

8. Rodrigues GRI, Lewis DR, Fichino SN. Steady-state auditory evoked responses in audiological diagnosis in children: a comparison with brainstem evoked auditory responses. Braz J Otorhinolaryngol. 2010;76(1):96-101.

9. Han D, Mo L, Liu H, Chen J, Huang L. Threshold estimation in children using auditory steady-state responses to multiple simultaneous stimuli. ORL J Otorhinolaryngol Relat Spec. 2006;68(2):64-8.

10. Linares AE, Costa-Filho AO, Martinez MANS. Auditory steady state response in pediatric audiology. Braz J Otorhinolaryngol. 2010;76(6):723-8.

11. Rance G, Dowell RC, Rickards FW, Beer De, Clark GM. Steadystate evoked potential and behavioral hearing threshold in a group of children absent click-evoked auditory brainstem response. Ear Hear. 1998;19(1):48-61.

12. Rance G, Rickards FW. Prediction of hearing threshold in infants using auditory steady-state evoked potentials. J Am Acad Audiol. 2002;13(5):236-45.

13. Sleifer P, da Costa SS, Cóser PL, Goldani MZ, Dornelles C, Weiss K. Auditory brainstem response in premature and full-term children. Int $\mathrm{J}$ Pediatr Otorhinolaryngol. 2007;71(9):1449-56.

14. Matas CG, Magliaro FCL. Introdução aos Potenciais Evocados Auditivos e Potencial Evocado Auditivo de Tronco Encefálico. In: Bevilaqua MC, Martinez MAN, Balen SA, Pupo AC, Reis ACMB, Frota S. Tratado de Audiologia. São Paulo: Santos; 2011. p. 181-95.
15. Rance G, Roper R, Simons L, Moody L-J, Paulis C, Dourlay M, et al. Hearing threshold estimation in infants using auditory steady-state responses. J Am Acad Audiol. 2005;16(5):291-300.

16. Werff KRV, Brown CJ, Gienapp BA, Clay KMS. Comparison of auditory steady-state response and auditory brainstem response thresholds in children. J Am Acad Audiol. 2002;13(5):227-35.

17. Ferraz OB, Freitas SV, Marchiori LLM. Análise das respostas obtidas por Potenciais Evocados Auditivos de Estado Estável em indivíduos normais. Rev Bras Otorrinolaringol. 2002;68(4):480-6.

18. Chou Y-F, Chen P-R, Yu S-H, Wen Y-H, Wu H-P. Using multi-stimulus auditory steady-state response to predict hearing thresholds in high-risk infants. Eur Arch Otorhinolaryngol. 2012;269(1):73-9.

19. Calil DB, Lewis DR, Fiorini AC. Achados dos Potenciais Evocados Auditivos de Estado Estável em crianças ouvintes. Distúrb Comum. 2006;18(3):391-401.

20. Duarte JL, Alvarenga KF, Garcia TM, Costa-Filho AO, Lins OG. A resposta auditiva de estado estável na avaliação auditiva: aplicação clínica. Pró-Fono R Atual Cient. 2008;20(2):105-10.

21. Bucuvic EC, Iório MCM. Resposta auditiva de estado estável. In: Bevilaqua MC, Martinez MAN, Balen SA, Pupo AC, Reis ACMB, Frota S. Tratado de Audiologia. São Paulo: Santos; 2011. p. 495-515.

22. Dimitrijevic A, John MS, Roon PV, Purcell DW, Adamonis J, Ostroff $\mathrm{J}$, et al. Estimating the audiogram using multiple auditory steady-state responses. J Am Acad Audiol. 2002;13(4):205-24.

23. Emara AA, Gabr TA. Auditory steady state response in auditory neuropathy. J Laryngol Otol. 2010;124(9):950-6.

24. Lins OG, Picton TW, Brigitte L, Durieux-Smith A, Champagne SC, Moran LM, et al. Frequency-specific audiometry using steady-state responses. Ear Hear. 1996;17(2):81-96.

25. Swanepoel D, Hugo R, Roode R. Auditory steady-state responses for children with severe to profound hearing loss. Arch Otolaryngol Head Neck Surg. 2004;130(5):531-5.

26. Jerger J. Clinical experience with impedance audiometry. Arch Otolaryngol. 1970;92(4):311-24.

27. Gravel JS. Audiologic assessment for the fitting of hearing instruments: big challenges from tiny ears. In: Seewald RC. A sound foundation through early amplification. National Center of Audiology; 2000; London; Ontario, Canada. Proceedings.

28. Versollato MC. Relações entre o desenvolvimento sensório motor características individuais e desempenho na audiometria de reforço visual em crianças com cinco a nove meses de idade [dissertação]. São Paulo: Pontifícia Universidade Católica de São Paulo; 2005.

29. Ramos N, Almeida MG, Lewis DR. Correlação dos achados do PEATEFE e da avaliação comportamental em crianças com deficiência auditiva. Rev CEFAC. 2013;15(4):796-802.

30. Beck RM, Ramos BF, Grasel SS, Ramos HF, de Moraes MF, de Almeida ER, et al. Comparative study between pure tone audiometry and auditory steady-state responses in normal hearing subjects. Braz J Otorhinolaryngol. 2014;80(1):35-40. 